\title{
Taxonomic assessment of Allium species from Kazakhstan based on ITS and matK markers
}

Saule Abugalieva', Lyubov Volkova', Yuliya Genievskaya', Anna Ivaschenko², Yuri Kotukhov³, Gulzhahan Sakauova ${ }^{4}$ and Yerlan Turuspekov ${ }^{1 *}$

From Belyaev Conference

Novosibirsk, Russia. 07-10 August 2017

\begin{abstract}
Background: As part of nation-wide project to infer the genetic variation of the native flora in Kazakhstan, a study was attempted to assess phylogenetic relationships of endemic and rare Allium species. In total, 20 Allium species were collected in field trips in five different regions of Kazakhstan during 2015-2016. Most species (9) were collected in the southern part of the country along of Karatau mountains, followed by Altai mountains (5) in eastern Kazakhstan. The ITS and matK DNA regions were applied in order to assess the taxonomic relationships among species. The major goal of the study was to assess the taxonomic position of five endemic and rare species from Allium subgenus Reticulatobulbosa collected in Karatau mountains of Southern Kazakhstan.

Results: The 20 collected Allium species were assessed using morphological traits and a DNA barcoding approach. The morphological analyses of four different species in subgenus Reticulatobulbosa inferred similarities of $A$. inconspicuum and A. barszchewskii (both from section Companulata) that were separated from A. oreoscordum and A. oreoprasoides (section Nigrimontana) by several traits, including form of bulbs and leaves, presence of bracts, shape of perianth lobes and style. The Neighbor-Joining method was applied to generate ITS and matK phylogenetic trees for two groups of populations: 1) 20 Allium species collected within the project, and 2) 50 Allium worldwide species.

Conclusions: The analyses of nucleotide sequences of ITS and matK robustly confirmed the monophyletic origin of the Allium species. The variability in 20 local Allium species in ITS was 6.6 higher than in matK, therefore the topology of the ITS tree was better resolved. The taxonomy of Allium species largely coincided with a recent classification of this genus. Analyses of both ITS and matK suggest that $A$. oreoscordum is genetically close to $A$. oreoprasoides in section Nigrimontana of subgenus Reticulatobulbosa. This result was also confirmed using morphological description of individual plants of four species in subgenus Reticulatobulbosa. The study is another contribution to taxonomy clarification in Allium.
\end{abstract}

Keywords: Allium taxonomy, ITS, matK, DNA barcoding, Subgenus Reticulatobulbosa

\footnotetext{
* Correspondence: yerlant@yahoo.com

${ }^{1}$ Institute of Plant Biology and Biotechnology, Almaty, Kazakhstan

Full list of author information is available at the end of the article
} International License (http://creativecommons.org/licenses/by/4.0/), which permits unrestricted use, distribution, and reproduction in any medium, provided you give appropriate credit to the original author(s) and the source, provide a link to the Creative Commons license, and indicate if changes were made. The Creative Commons Public Domain Dedication waiver (http://creativecommons.org/publicdomain/zero/1.0/) applies to the data made available in this article, unless otherwise stated. 


\section{Background}

Allium is one of the largest widespread genus in the Northern Hemisphere and it consists of more than 850 species [1]. The taxonomy of the Allium is well described in a number of classical botanical reviews [2, 3] and molecular genetics studies $[1,4]$. Several initial publications based on DNA markers suggested polyphyletic origin of studied subgenera [5-7]. However, Friesen and co-authors [8] criticized this conclusion and noted the omission of species in analyzed subgenera and questioned the quality of studied materials in these publications. In the same report, Friesen et al. [8] proposed a new classification of Allium based on using rDNA ITS (internally transcribes spacers) sequences. The study suggested that Allium has a monophyletic origin and consists of three evolutionary lines with 15 subgenera and 72 sections. This classification was supported in several later studies [9-12] and became well adopted among Allium taxonomists. In spite of these substantial efforts towards understanding of evolutionary processes and taxonomy of the genus there are still many poorly described Allium taxa available in different parts of the World and active description of wild onion species is an ongoing process $[1,13,14]$.

The Central Asian region, including Kazakhstan, is one of the important regions to study the evolution and distribution of Allium species. Kazakhstan is the largest Central Asian republic with total area of 2.7 million $\mathrm{km}^{2}$, which is ranking it as ninths largest country in the World by territory. The country is land locked and has rather unique flora consisting of about 6000 species with approximately $10 \%$ of them endemic to this region. Despite richness and uniqueness of the local flora and enormous volume of botanical studies, the plant community is still poorly characterized by using modern DNA based studies. There are only few examples in the literature suggesting taxonomy evaluation of wild plant species from this country, including in assessment of genetic variation in annual [15] and perennial species [16, 17]. This trend is slowly changing due to the launch of a new nation-wide research program [18] that combine efforts of local botanists and geneticists from Biotechnology Research Organizations, Botanical Gardens, State Nature Parks and Reserves. One of the examples of this trend is this collaborative study on reassessment of the taxonomy of Allium species growing in this region. According to Abdulina [19] there are 120 Allium species growing in different parts of the country. One of the regional hot spots of Allium diversity in Kazakhstan is the Karatau State Natural Reserve located in the southern part of Kazakhstan. Therefore, endemic, rare and economically important species of Allium in Karatau were a particular target in this study with a major focus on species in subg. Reticulatobulbosa.

Currently DNA barcoding tools [20] have been considered as one of the most informative and efficient approaches in evaluation of plant phylogeny, and successfully used in the molecular taxonomy of Allium [5]. The approach is based on alignment of short sequences of universal DNA markers from the nuclear and plastid genomes [21-23], and was applied in this study as well. The scope of the study was to assess of distribution areas of growth for endemic and rare Allium species in Kazakhstan, describe morphological patterns of poorly studied species, and clarify phylogenetic relationship of native species using a DNA barcoding approach. In particularly, we present the results of botanical and molecular phylogeny analysis of species in subg. Reticulatobulbosa native to Karatau State Nature Reserve in Southern Kazakhstan.

\section{Results \\ Collecting Allium species in different regions of Kazakhstan}

During 2015-2016 several collecting efforts in five regions of the country were conducted with the goal to sample endemic and rare Allium species. The summary of collecting trips is given in Table 1 and collecting areas are shown in Fig. 1. The area of sampling was stretched from Altai mountains in the east of the country to Ustyurt Plateau in the west. The highest number of Allium species was collected in southern Kazakhstan (9), including the mountainous area of Karatau State Nature Reserve. The geography of sampling areas varied from flat regions to mountainous areas and ranged from $96 \mathrm{~m}$ above sea level in Western Kazakhstan (A. caspium) to $2669 \mathrm{~m}$ in southern Kazakhstan (A. caricoides, Additional file 1), although within this project only a portion of the available wild onion species of the country were collected.

Evaluation of published Allium related literature suggested that species in sections Nigrimontana and Campanulata in subgen. Reticulatobulbosa are native to Karatau mountains in southern Kazakhstan and previously were poorly studied. Particularly, A. oreoscordum was not previously classified to any existing sections of Reticulatobulbosa and not mentioned by Friesen et al. [8]. The description of three species in Table 1 suggested they have similarities with $A$. oreoscordum in a number of traits, including peduncle length and samina filaments. At the same time, size of spathe and color of perianth lobes differentiated $A$. oreoscordum from the other three species. Also, traits such as form of bulbs and leaves, presence of bracts, shape of perianth lobes and style were similar for $A$. oreoscordum and 
Table 1 Morphological description of four Allium species in subgenus Reticulatobulbosa

\begin{tabular}{|c|c|c|c|c|}
\hline Species & A.oreoprasoides & A.oreoscordum & A.inconspicuum & A. barszcewskii \\
\hline Section & Nigrimontana & Unknown & Companulata & Companulata \\
\hline Subgenus & Reticulatobulbosa & Reticulatobulbosa & Reticulatobulbosa & Reticulatobulbosa \\
\hline \multicolumn{5}{|l|}{ Traits: } \\
\hline Bulb & $\begin{array}{l}\text { Cylindrical-conical, } \\
0,5-1 \mathrm{~cm}\end{array}$ & $\begin{array}{l}\text { Narrow conical, } \\
\text { up to } 1 \mathrm{~cm} \text { wide }\end{array}$ & $\begin{array}{l}\text { Oblong, ovoid-like, } \\
0,5-1,5 \mathrm{~cm} \text { wide }\end{array}$ & $\begin{array}{l}\text { Conical, ovoid-like, } \\
0,7-1,5 \mathrm{~cm} \text { wide }\end{array}$ \\
\hline Tunics & Reddish-brown, reticulate & Brownish, reticulate & Brown, reticulate & Brown, reticulate \\
\hline Stem Length & $20-30 \mathrm{~cm}$, furrowed & $25-50 \mathrm{~cm}$ & $15-30 \mathrm{~cm}$, thin & $20-60 \mathrm{~cm}$ \\
\hline $\begin{array}{l}\text { Leaves (Number; } \\
\text { Width) }\end{array}$ & Linear, flat (4-6; 2-3 mm) & $\begin{array}{l}\text { Linear, flat (5-7; 3-5 mm, } \\
\text { hard, shorter than stems) }\end{array}$ & $\begin{array}{l}\text { Narrow-linear, filamentous, } \\
\text { furrowed }(1-2 ; 0,5-1 \mathrm{~mm} \text { in } \\
\text { width, a little shorter than } \\
\text { stems) }\end{array}$ & $\begin{array}{l}\text { Narrow-linear, smooth, } \\
\text { furrowed (1; } 1-3 \mathrm{~mm} \text {, } \\
\text { shorter than stems) }\end{array}$ \\
\hline Spathe & $\begin{array}{l}\text { With pointy end (1,5-2 } \\
\text { times shorter than umbela) }\end{array}$ & $\begin{array}{l}\text { Shortly-pointed (Equal to } \\
\text { umbela) }\end{array}$ & $\begin{array}{l}\text { Shortly-pointed ( } 3 \text { times } \\
\text { shorter than umbela) }\end{array}$ & $\begin{array}{l}\text { Shortly-pointed ( } 2-3 \text { times } \\
\text { shorter than umbela) }\end{array}$ \\
\hline Umbela & $\begin{array}{l}\text { Hemispherical or spherical/ } \\
\text { multiflorous, dense }\end{array}$ & Spherical / large, dense & $\begin{array}{l}\text { Bundle-like / non- } \\
\text { multiflorous, loose }\end{array}$ & $\begin{array}{l}\text { Bundle-like hemispherical / } \\
\text { multiflorous, dense }\end{array}$ \\
\hline Peduncle & $\begin{array}{l}\text { Equal to each other, } 2-3 \\
\text { times longer than perianth }\end{array}$ & $\begin{array}{l}\text { Almost equal to each other, } \\
1,5-3 \text { times longer than } \\
\text { perianth }\end{array}$ & $\begin{array}{l}\text { Almost equal to each other, } \\
\text { shorter, equal or longer than } \\
\text { perianth }\end{array}$ & $\begin{array}{l}\text { Unequal to each other, } 2-3 \\
\text { times longer than perianth }\end{array}$ \\
\hline Bracts & Present & Present & No & No \\
\hline $\begin{array}{l}\text { Perianth lobes } \\
\text { (Length; Outter) }\end{array}$ & $\begin{array}{l}\text { Pale pink with purple vein } \\
(4-5 \mathrm{~mm} \text {; Boat-shaped) }\end{array}$ & $\begin{array}{l}\text { Greenish-white on the back } \\
\text { (4 mm; Boat-shaped) }\end{array}$ & $\begin{array}{l}\text { Pale dirty-violet, darker on } \\
\text { the back ( } 8-11 \mathrm{~mm} \text {; Linear- } \\
\text { lanceolate) }\end{array}$ & $\begin{array}{l}\text { Pink-violet, pink, white } \\
\text { (7-14 mm; Lanceolate) }\end{array}$ \\
\hline Stamina filaments & $\begin{array}{l}0.25 \text { times longer than perianth, } \\
\text { fused with each other and } \\
\text { with perianth }\end{array}$ & $\begin{array}{l}1,5 \text { times longer than } \\
\text { perianth, fused with each } \\
\text { other and with perianth }\end{array}$ & $\begin{array}{l}2 \text { times shorter than } \\
\text { perianth, fused with } \\
\text { each other }\end{array}$ & $\begin{array}{l}1,5 \text { times shorter than } \\
\text { perianth, fused with each } \\
\text { other and with perianth on } \\
1 / 3-1 / 2\end{array}$ \\
\hline Style & $\begin{array}{l}\text { Significantly extends out of } \\
\text { corolla }\end{array}$ & Extends out of corolla & $\begin{array}{l}\text { Does not extend out of } \\
\text { corolla }\end{array}$ & $\begin{array}{l}\text { Does not extend out of } \\
\text { corolla }\end{array}$ \\
\hline
\end{tabular}

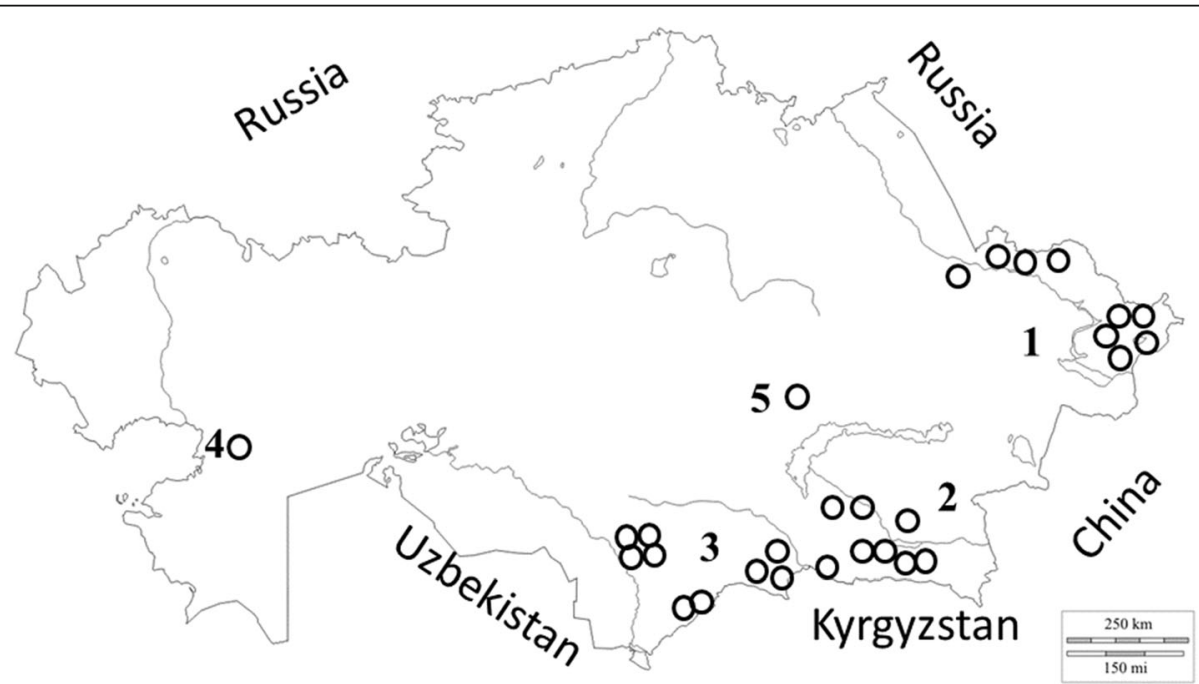

Fig. 1 Locations of the collecting sites (open circles) in five different regions of Kazakhstan - East, South-east, South, West, and Center. Arabic figures reflect regions of collecting sites - East, South-east, South, West, and Center of Kazakhstan) 
A.oreoprasoides (sect. Nigrimontana) and differentiated them from two species of sect. Companulata, A. inconspicuum and $A$. barszcewskii (Table 1 ).

\section{Phylogenetic study of Allium species}

Four different datasets were generated in this study. First two datasets were related to ITS sequences of local species and sequences for worldwide species collected from the NCBI database, respectively. Next two datasets were related to matK sequences for local and worldwide accessions from the NCBI database, respectively. The length of ITS in local accessions varied from $616 \mathrm{bp}$ (A. eriocoleum) to $638 \mathrm{bp}$ (A. fistulosum, A. altaicum, Additional file 2), and the alignment was adjusted by introducing gaps using MEGA 5.0. This resulted in $671 \mathrm{bp}$ as a total alignment length. The number of polymorphic nucleotides was 415 , or $61.8 \%$ out of the total number of nucleotides (Additional file 2). The length of matK was more conservative and varied from $779 \mathrm{bp}$ in A. caesium and A. sabulosum to $788 \mathrm{bp}$ in all remaining species (Additional file 3 ). The number of polymorphic sites in matK for all local species was 73 , or $9.3 \%$ out of total number of nucleotides
(Additional file 3). Therefore, in this study the variability of ITS was in 6.6 times higher than matK.

\section{Genetic analysis of local Allium species using ITS (dataset 1)}

In total 20 collected species from Kazakhstan listed in Additional file 1 were analyzed using ITS sequences. The Neighbor-Joining phylogenetic tree constructed by using four outgroup species separated 20 species in two distinct clades. Figure 2 provides relationships of these Allium species.

The first clade included species from subgenera Anguinum, Porphyroprason, Vvedenskaya, and Melanocronium, which are part of the second evolutionary line. The second clade included species that part of third evolutionary line. Species in subgenus Cepa formed a sister subclade with other subclade consisting from $A$. caricoides and species in subgenus of Reticulatobulbosa. The species in the subgenus Reticulatobulbosa have formed a separate group within the second clade, and the $A$. oreoprasoides was the closest taxon to the $A$. oreoscordum.

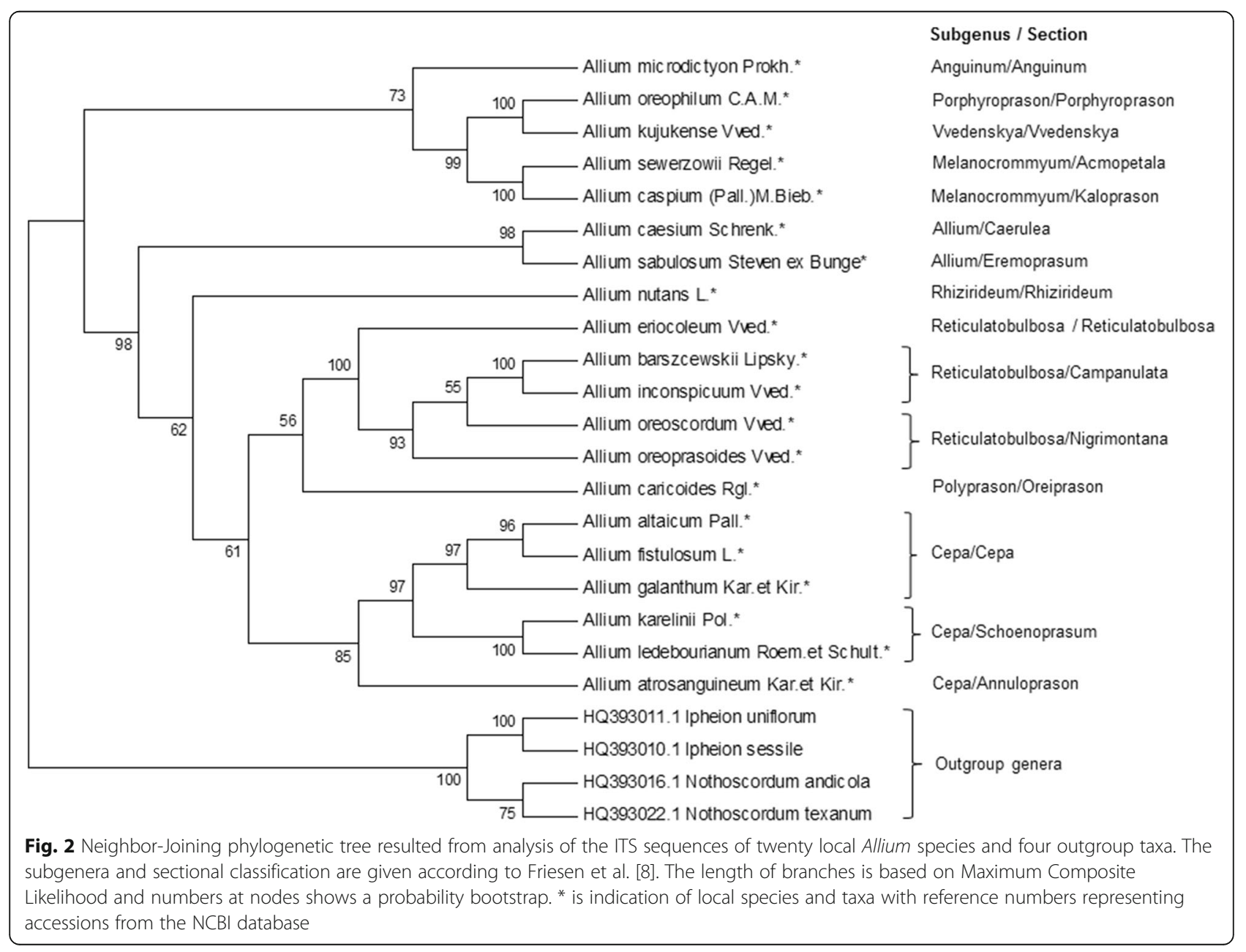




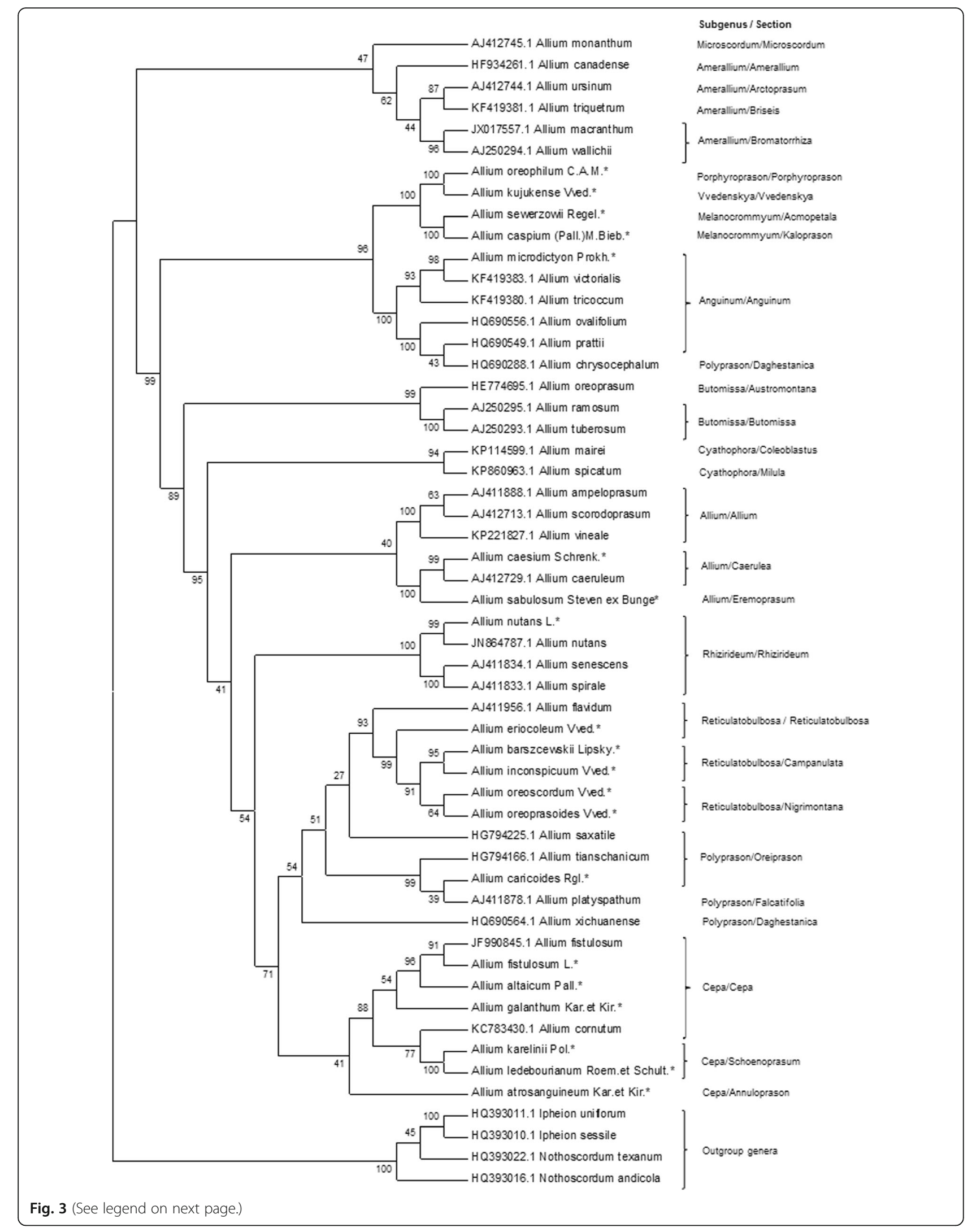


(See figure on previous page.)

Fig. 3 Neighbor-Joining phylogenetic tree resulted from analysis of the ITS sequences of twenty local, thirty worldwide Allium species and four outgroup taxa. The subgenera and section classification are given according to Friesen et al. [8]. The length of branches is based on Maximum Composite Likelihood and numbers at nodes shows a probability bootstrap. ${ }^{*}$ is indication of local species and taxa with reference numbers representing accessions from the NCBI database

\section{Genetic analysis of $s$ set of worldwide occurring Allium species using ITS dataset (dataset 2)}

The dataset 2 included ITS sequences of 50 Allium species, consisting of 20 local and 30 worldwide distributed species available at the NCBI database. (Fig. 3).

The generated phylogenetic tree was in congruence with results from the first dataset and supported the theory of a monophyletic Allium origin. The only misplaced species in the phylogenetic tree in this study was $A$. chrysocephalum (subg. Polyprason, sect. Daghestanica), which was grouped together with species from subg. Anguinum. The topology of the tree is suggesting that species in subg. Reticulatobulbosa derived from species in subgenus Polyprason (Fig. 3) and formed a subclade, which is a sister subclade to species in subg. Cepa.
Within Reticulatobulbosa, similarly to the results from the analysis of the dataset $1, A$. inconspicuum and $A$. barszchewskii formed a sister group, and $A$. oreoprasoides and $A$. oreoscordum formed a second one. The bootstrap support was $91 \%$.

\section{Genetic analysis of local Allium species using matK dataset (dataset 3)}

The study of dataset 3 was based on the analysis of sequences from 20 local Allium species of plastid genome marker matK (Fig. 4).

The Neighbor-Joining dendrogram generated three distinct clades with the first clade containing species from subgenera Melanocronium, Vvedenskaya, and Porphyroprason; the second clade with species in subgenera

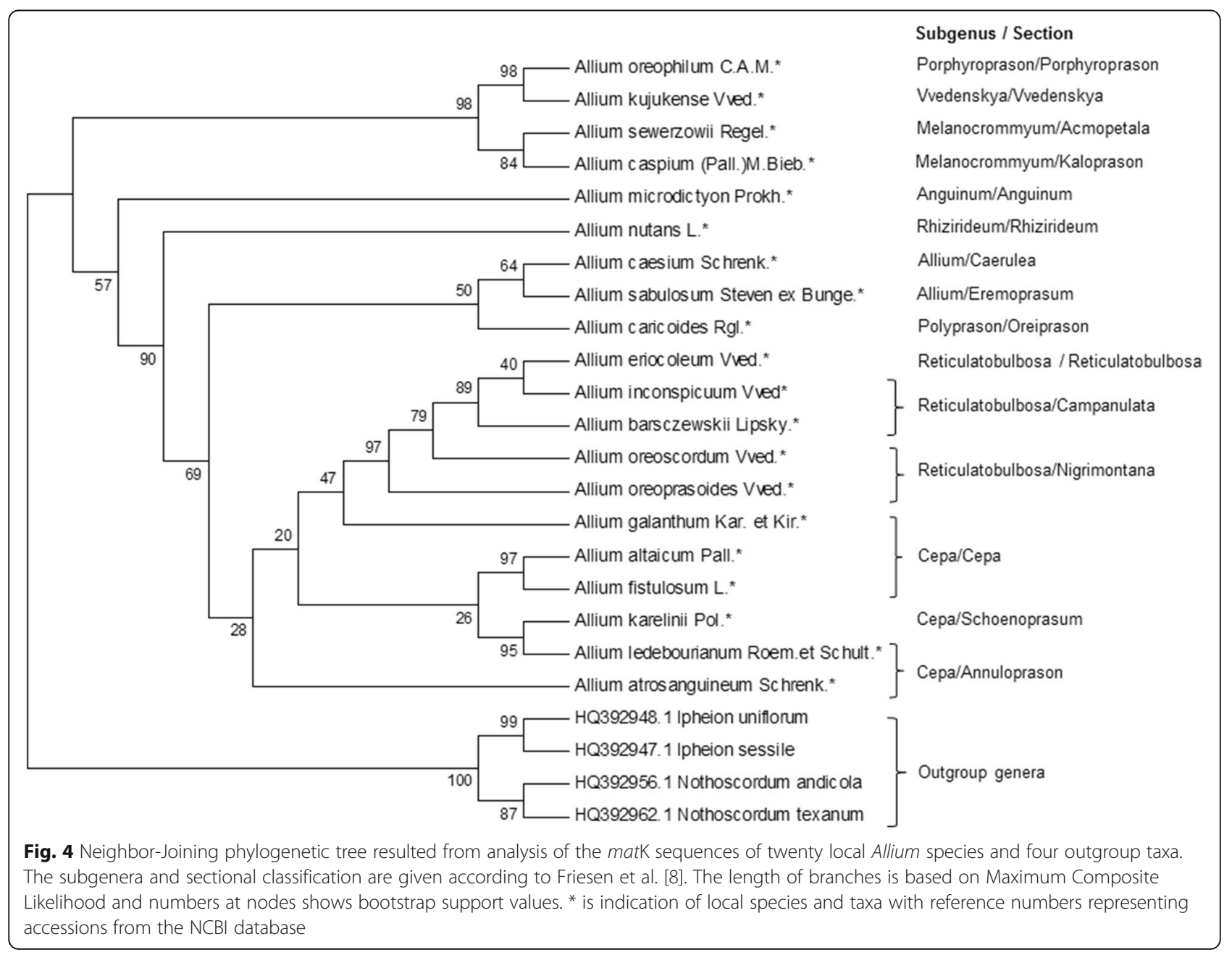


Allium and Polyprason; and the third clade with species of subgenera Cepa and Reticulatobulbosa. In the topology of the tree A. microdictyon and A. nutans showed intermediate positions between groups of the first and the second evolutionary lines, although the former species was closer to the first evolutionary lines and latter to the second line. As in the ITS tree, the results within Reticulatobulbosa suggested close genetic relationship between A. oreoprasoides and A. oreoscordum.

\section{Genetic analysis of worldwide occurring Allium species using matK dataset (dataset 4)}

As in the ITS study, the generated matK phylogenetic tree supported the theory of a monophyletic Allium origin. However, unlike the study of dataset 2, the analysis of 50 accessions using matK has not confirmed the topology of Allium groups based on three generated clades (Fig. 5) containing species attributed to the three evolutionary lines.

The first difference was that species in subgenera $\mathrm{Mel}$ anocronium, Vvedenskaya, and Porphyroprason (second evolutionary line) were grouped together with subgenera Amerallium and Microscordum (first evolutionary line). The second difference in the phylogenetic tree was the grouping of species in subgen. Butomissa (third evolutionary line) together with species in Anguinum (second evolutionary line) in the same clade. However, A. oreoprasoides and A. oreoscordum in subgenus Reticulatobulbosa were again positioned together with bootstrap support of $88 \%$ (Fig. 5).

\section{Discussion}

Although the variability of matK in Allium species is smaller than in ITS, the phylogenetic trees using markers from two different genomes confirmed earlier findings of monophyletic origin in Allium genus [8, 14]. Our data suggested that the collected 20 local Allium species belong to subgenera in the second and third evolutionary lines postulated by Friesen et al. [8]. The notable difference between the results from datasets 1 and 3 is that unlike in ITS, the dendrogram in the mat $\mathrm{K}$ analysis is suggesting that species in subgen. Cepa evolved earlier than those in subgen. Reticulatobulbosa, and these two subgenera have a common ancestral node (Fig. 4). Similar results can be seen from the observations of phylogenetic trees from datasets 2 and 4, which include larger numbers of taxa added from the NCBI database. The analysis of dataset 4 based on matK sequences (Fig. 5) is suggesting that species in Reticulatobulbosa evolved from species in subgen. Cepa. This result is not in congruence with the recent classification [8] of Allium, and most probably can be explained by lower variability in matK. Therefore, most important output can be observed from the ITS topology of phylogenetic tree for study of worldwide species (dataset
2). Unlike in phylogenetic tree generated in [8], where subclades Polyprason, Reticulatobulbosa and Cepa formed three sister subclades, in this study only two subclades were detected. The first subclade was species from subgenera Cepa, while second one consisted from species of Polyprason and Reticulatobulbosa. The other misplacement of species in the worldwide ITS phylogenetic tree was a grouping of A. chrysocephalum (subgenus Polyprason, section Daghestanica) together with species from subgenus Anguinum, which may potentially happened due to inaccuracies of sequences in the database.

In this study five endemic and rare species within subgenus Reticulatobulbosa, representing sections Reticulatobulbosa, Companulata, and Nigrimontana were analyzed. All five species were collected in Karatau Mountains (black mountains in translation from Kazakh) in South Kazakhstan region. The name of the section Nigrimontana is coinciding with the name of these mountains, and most probably related to this place and reflects richness and uniqueness of the local flora, including in possessing of many wildly growing onion species [24]. The phylogeny of both ITS and matK is suggesting that within subgenus three sub groups can separated. The representative of the first group is A. eriocoleum (section Reticulatobulbosa) was positioned mostly apart from the remaining four species (Figs. 2, 3, 5). In all four datasets, the A. oreoprasoides (section Nigrimontana) and A. oreoscordum formed second sub group, while $A$. inconspicuum and $A$. barszchewskii (both species from section Companulata) formed third sub group. Based on these findings the $A$. oreoscordum with high probability can be positioned in the section Nigrimontana. Morphological description of species from sections Nigrimontana and Companulata (Table 1) can be used as an additional confirmation for this assumption.

The result of this study was an initial effort in large scale project oriented in thorough description of endemic and rare species in Kazakhstan based on DNA barcoding approach. It was determined that in the analysis of 20 local Allium accessions the level of variability in ITS was 6.6 higher than in matK. The other important result was an assessment of taxonomic statuses of endemic and rare Allium species growing in Kazakhstan. The study confirms monophyletic origin of Allium genus that was established in several published reports $[8,13,14]$. In addition, a detailed study on comparison of Reticulatobulbosa species was performed with a major attention to morphological and molecular genetic description of species grown in Karatau State Natural Reserve.

\section{Conclusions}

Despite fundamental study on phylogenetic taxonomy of Allium genus by Friesen and co-authors [8], there are still many poorly described Allium taxa available in 


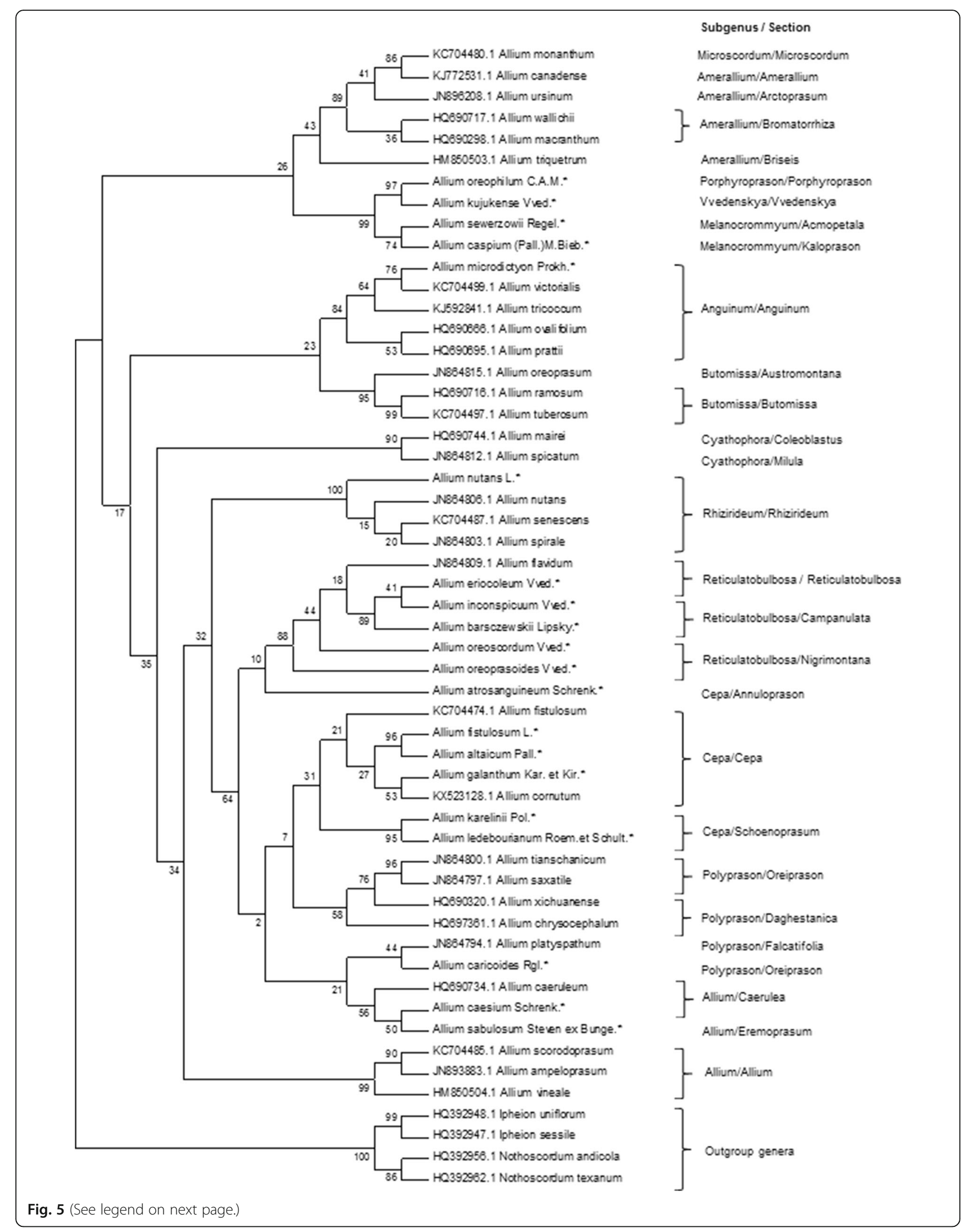


(See figure on previous page.)

Fig. 5 Neighbor-Joining phylogenetic tree resulted from analysis of the matK sequences of twenty local and thirty worldwide occurring Allium species and four outgroup taxa. The subgenera and sectional classification are given according to Friesen et al. [8]. The length of branches is based on Maximum Composite Likelihood and numbers at nodes shows bootstrap support values (\%). * indicates local species and taxa with reference numbers representing accessions from the NCBI database

different parts of the World. In this study, in order to assess the phylogeny of 20 endemic, rare and economically important Allium species from Kazakhstan, two DNA barcoding markers ITS and matK were applied. The obtained results suggested that the variability of ITS sequences in studied 20 Allium species was in 6.6 times higher than in matK. Generated phylogenetic trees using ITS sequences were well in congruence with existing new phylogenetic classification (Friesen et al., 2006) and confirmed monophyletic origin of the genus. Both ITS and $m a t K$ analyses suggested that regional endemic $A$. oreoscordum with high probability can be positioned in the section Nigrimontana of the subgenus Reticulatobulbosa. This result was also confirmed by the assessment of morphological traits for four different Allium species in the subgenus Reticulatobulbosa. The study is another contribution to taxonomy clarification in Allium.

\section{Methods}

\section{Plant material}

Collecting trips were organized in 2015 and 2016 in five different regions of the country (Fig. 1) and resulted in sampling of 20 different endemic, rare and economically important Allium species.

The locations and geographic characterizations of the collecting sites are provided in the table (Additional file 1). Voucher specimens were deposited in the herbarium of the Institute of Plant Biology and Biotechnology (Kazakhstan). From five to ten plants were described for each species in every collecting site (Table 1). The elevation from above sea level is ranged from 96 to $2669 \mathrm{~m}$. Leaf samples of plants growing distantly apart were collected in plastic bags containing silica gel for DNA extraction.

Table 2 Primers for ITS1-5.8S-ITS2 region and matK gene

\begin{tabular}{llll}
\hline Primers & Nucleotide sequence & $\begin{array}{l}\text { Annealing } \\
\text { temperature }\end{array}$ & $\begin{array}{l}\text { Amplicon } \\
\text { sizes }\end{array}$ \\
\hline ITS1nF & 5'-AGAAGTCGTAACAAGGTT $^{\prime}$ ITS4nR & $58^{\circ} \mathrm{C}$ & $638 \mathrm{bp}$ \\
& $\begin{array}{l}\text { CCGTAGG- 3' } \\
\text { 5'-TCCTCCGCTTATTGATATG }\end{array}$ & & \\
& C- 3' & & \\
matK-F & 5'-CCTATCCATCTGGAAATCTT $^{\prime}$ & $50^{\circ} \mathrm{C}$ & $788 \mathrm{bp}$ \\
matK-R & AG- 3' & & \\
& 5'-GTTCTAGCACAAGAAAGTC \\
& G- 3' & & \\
\hline
\end{tabular}

DNA extraction, amplification and sequencing.

Total genomic DNA was extracted from dry or fresh leaves according to the Dellaporta DNA extraction protocol [25]. PCR fragments were amplified from the maturase $\mathrm{K}$ gene in chloroplast genome (matK) and the nuclear ribosomal complex including the internal transcribed spacers 1 and 2, and 5.8S rRNA.

All PCR reactions were performed in total $16 \mu \mathrm{l}$ volumes in Veriti Thermo cycler (Applied Biosystems, Foster City, CA, USA). Nucleotides sequences of ITS [26] and matK [20] primers and sizes of amplicons are represented in Table 2.

Whole volume of each PCR products was checked by electrophoresis in $1.5 \%$ agarose gel at $80 \mathrm{~V}$ voltage for $40 \mathrm{~min}$. Single bands with expected sizes for matK and ITS were visualized, cuted out from gel and purified using ULTRAPrep ${ }^{\circ}$ Agarose Gel Extraction Mini Prep Kit (AHN Biotechnologie GmbH, Nordhausen, Germany) according to the protocol provided by the company. Purified DNA amplicons were used for the sequence reactions with forward and reverse primers separately. All reactions were performed with the BigDye Terminator Cycle Sequencing technology (Applied Biosystems, Foster City, CA, USA) according to protocols of the company.

\section{Alignment and phylogenetic analyses}

Generated sequences of local Allium samples were imported in MEGA 5 software [27] and aligned by using ClustalW program [28]. In addition, the sequences for ITS and matK of local species were aligned with sequences of Allium species from the NCBI reference database [29]. For the construction of phylogenetic tree the Maximum Composite Likelihood model [30], Neighbor-Joining statistical method [31], and the 1000 replication bootstrap test were used.

\section{Additional files}

Additional file 1: The list of Allium species collected in five regions of Kazakhstan (2015-2016). Endemic species were highlighted in bold. (PDF $312 \mathrm{~kb}$ )

Additional file 2: Polymorphic sites of ITS in twenty Allium species collected in Kazakhstan. (XLSX $44 \mathrm{~kb}$ )

Additional file 3: Polymorphic sites of matK in twenty Allium species collected in Kazakhstan. (XLSX 15 kb)

Acknowledgements

The authors would like to acknowledge the funding from the Ministry of Education and Sciences of the Republic of Kazakhstan for national program 
N0237 and support from the officials of Karatau State Nature Reserve for organized collecting trips.

\section{Funding}

Publication of this article has been funded by the specific allocation in the budget of the national program N0237 provided by the Ministry of Education and Sciences of the Republic of Kazakhstan. The funder did not participate in study design, data collection and analysis, decision to publish, or preparation of the manuscript.

\section{Availability of data and materials}

The datasets supporting the conclusions of this article are included within the article. The voucher specimens are deposited in the herbarium of the Institute of Plant Biology and Biotechnology (Kazakhstan).

\section{About this supplement}

This article has been published as part of BMC Plant Biology Volume 17 Supplement 2, 2017: Selected articles from Belyaev Conference 2017: plant biology. The full contents of the supplement are available online at https://bmcplantbiol.biomedcentral.com/articles/supplements/volume-17supplement-2.

\section{Authors' contributions}

SA and YT carried out the experimental design. Al, YK, and GS collected Allium species, performed morphological descriptions and developed herbarium specimens. LV carried out the DNA extraction, DNA sequencing and the alignment of sequences. SA, YT and YG participated in preparation of the manuscript. All authors reviewed the draft of the manuscript. All authors read and approved the final manuscript.

\section{Ethics approval and consent to participate}

This study does not contain any research requiring ethical consent or approval.

\section{Consent for publication}

Not applicable.

\section{Competing interests}

The authors declare they have no competing interests.

\section{Publisher's Note}

Springer Nature remains neutral with regard to jurisdictional claims in published maps and institutional affiliations.

\section{Author details}

'Institute of Plant Biology and Biotechnology, Almaty, Kazakhstan. ${ }^{2}$ Ile-Alatau State National Nature Park, Almaty, Kazakhstan. ${ }^{3}$ Altai Botanical Garden, Ridder, Kazakhstan. ${ }^{4}$ Karatau State Nature Reserve, Kentau, Kazakhstan.

\section{Published: 28 December 2017}

\section{References}

1. Wheeler EJ, Mashayekhi S, McNeal DW, Columbus JT, Pires JC. Molecular systematics of Allium subgenus Amerallium (Amaryllidaceae) in North America. Am J Bot. 2013;100(4):701-11.

2. Traub HP. The subgenera, sections and subsections of Allium L. Plant Life. 1968:24:147-63.

3. Kamelin RV. Florogeneticheskij analiz estestvennoj flory gornoj Srednej Azii [Florogenetic analysis of natural mountain flora in middle Asia]. Nauka. 1973:354.

4. Fay MF, Rudall PJ, Chase MW. Molecular studies of subfamily Gilliesioideae (Alliaceae). Aliso. 2006;22(1):367-71.

5. von Berg GL, Samoylov A, Klaas M, Hanelt P. Chloroplast DNA restriction analysis and the infrageneric grouping of Allium (Alliaceae). Plant Syst Evol. 1996;200(3-4):253-61.

6. Samoylov A, Friesen N, Pollner S, Hanelt P. Use of chloroplast DNA polymorphisms for the phylogenetic study of Allium subgenus Amerallium and subgenus Bromatorrhiza (Alliaceae) II. Feddes Repertorium. 1999;110(12):103-9.

7. Mes TH, Fritsch RM, Pollner S, Bachmann K. Evolution of the chloroplast subg. Melanocrommyum. Genome. 1999;42(2):237-47.
8. Friesen N, Fritsch RM, Blattner FR. Phylogeny and new intrageneric classification of Allium (Alliaceae) based on nuclear ribosomal DNA ITS sequences. Aliso. 2006;22:372-95.

9. Chase MW, Reveal JL, Fay MF. A subfamilial classification for the expanded asparagalean families Amaryllidaceae, Asparagaceae and Xanthorrhoeaceae. Bot J Linn Soc. 2009;161:132-6.

10. Choi HJ, Davis AR, Cota-Sánchez JH. Comparative floral structure of four new world Allium (Amaryllidaceae) species. Syst Bot. 2011;36(4):870-82.

11. Hirschegger P, Jaške J, Trontelj P, Bohanec B. Origins of Allium ampeloprasum horticultural groups and a molecular phylogeny of the section Allium (Allium; Alliaceae). Mol Phylogenet Evol. 2010;54(2):488-97.

12. Choi HJ, Giussani LM, Jang CG, Oh BU, Cota-Sánchez JH. Systematics of disjunct northeastern Asian and northern north American Allium (Amaryllidaceae). Botany. 2012;90(6):491-508.

13. Nguyen $\mathrm{NH}$, Driscoll HE, Specht CD. A molecular phylogeny of the wild onions (Allium; Alliaceae) with a focus on the western north American center of diversity. Mol Phylogenet Evol. 2008;47(3):1157-72.

14. Li QQ, Zhou SD, He XJ, Yu Y, Zhang YC, Wei XQ. Phylogeny and biogeography of Allium (Amaryllidaceae: Allieae) based on nuclear ribosomal internal transcribed spacer and chloroplast rps16 sequences, focusing on the inclusion of species endemic to China. Ann Bot. 2010; 106(5):709-33

15. Turuspekov Y, Abugalieva S, Ermekbayev K, Sato K. Genetic characterization of wild barley populations (Hordeum vulgare Ssp. spontaneum) from Kazakhstan based on genome wide SNP analysis. Breed Sci. 2014;64(4):399-403.

16. Adams RP, Turuspekov Y. Taxonomic reassessment of some central Asian and Himalayan scale-leaved taxa of Juniperus (Cupressaceae) supported by random amplification of polymorphic DNA. Taxon. 1998;47:75-84.

17. Turuspekov Y, Adams RP, Kearney CM. Genetic diversity of three perennial grasses from the Semipalatinsk nuclear testing region of Kazakhstan after long-term nuclear testing radiation exposure. BSE. 2002;30:809-17.

18. Turuspekov Y, Abugalieva S. Plant DNA barcoding project in Kazakhstan. Genome. 2015;58(5):290.

19. Abdulina SA. Spisok sosudistykh rasteniy Kazakhstana [checklist of vascular plants of Kazakhstan]. Ed. by Kamelin RV. Almaty; 1998;18-21 p.

20. Abdulina SA. Spisok sosudistykh rasteniy Kazakhstana [The checklist of vascular plants of Kazakhstan]. Ed. Kamelin RV. Almaty: Alma-ata; 1998;18-21. doi:10.1371/journal.pone.0019254

21. Li X, Yang Y, Henry RJ, Rossetto M, Wang Y, Chen S. Plant DNA barcoding: from gene to genome. Biol Rev. 2015;90:157-66.

22. Hebert PDN, Gregory TR. The promise of DNA Barcoding for taxonomy. Syst Biol. 2005;54(5):852-9.

23. Kress WJ. Plant DNA barcodes: applications today and in the future. JSE. 2017; https://doi.org/10.1111/jse.12254.

24. Kamelin RV. Flora Syrdariinskogo Karatau: Materialy k floristicheskomu raionirovaniyu Srednej Azii [Flora of Syrdariya's Karatau; proceedings to floristic description of middle Asia]. Leningrad: Nauka; 1990. p. 146.

25. Dellaporta SL, Wood J, Hicks JB. A plant DNA mini preparation: version II. Plant Mol Biol Report. 1983;1:19-21.

26. White TJ, Bruns T, Lee S, Taylor JW. PCR protocols: a guide to methods and applications. In: Innis MA, Gelfand DH, Sninsky JJ, White TJ, editors. Amplification and direct sequencing of fungal ribosomal RNA genes for phylogenetics. New York: Academic Press, Inc.; 1990.

27. Tamura K, Peterson D, Peterson N, Stecher G, Nei M, Kumar S. MEGA5: molecular evolutionary genetics analysis using maximum likelihood evolutionary distance, and maximum parsimony methods. Mol Biol Evol. 2011:28(10):2731-9.

28. Chenna R, Sugawara H, Koike T, Lopez R, Gibson TJ, Higgins DG, Thompson JD. Multiple sequence alignment with the Clustal series of programs. Nucleic Acids Res. 2003;31(13):3497-500.

29. National Center for Biotechnology Information. U.S. National Library of Medicine, Rockville Pike, 1988. https://www.ncbi.nIm.nih.gov. Accessed 26 March 2017.

30. Tamura K, Nei M. Estimation of the number of nucleotide substitutions in the control region of mitochondrial DNA in humans and chimpanzees. Mol Biol Evol. 1993;10:512-26.

31. Saitou N, Nei M. The neighbor-joining method: a new method for reconstructing phylogenetic trees. Mol Biol Evol. 1987;4(4):406-25. 